\title{
Developing a new certified reference material of brown algae for trace metal analysis
}

\author{
A. Santoro, M. Ricci, M. F. Tumba-Tshilumba \& A. Held \\ European Commission- Joint Research Centre, \\ Institute for Reference Material and Measurements, Belgium
}

\begin{abstract}
A certified reference material (CRM) of brown algae is being developed at the Institute for Reference Materials and Measurements (IRMM), European Commission, Joint Research Centre, in order to supply academic and industrial analysts with a new tool useful in the environmental analysis of trace metals.

Sixty kg of raw brown algae (species Fucus vesiculosus) was collected from two different sites in Galway (Ireland) and processed according to ISO 34 and ISO 35. A large amount of milled and sieved (at $<125 \mu \mathrm{m}$ ) algae material was bottled and subjected to detailed homogeneity and stability tests with regard to the parameters to be certified.

The between bottle homogeneity of the total element content of $\mathrm{As}, \mathrm{Cd}, \mathrm{Cu}$, $\mathrm{Hg}, \mathrm{Pb}$, Se and $\mathrm{Zn}$ was assessed via a dedicated test, which confirmed the suitable homogeneity of the candidate CRM. The short term stability of the material when stored at high temperature $\left(60^{\circ} \mathrm{C}\right)$ for up to 4 weeks was also considered, confirming no degradation under the conditions applied.

Milled and sieved algae was also checked for water content by using KarlFischer titration and several oven temperatures (from $85^{\circ} \mathrm{C}$ to $110^{\circ} \mathrm{C}$ ) in order to establish the most reliable water determination method for the material.

Along with these studies, a long term stability isochronous study and the characterisation of the total element content for the above-mentioned metals by using an inter-laboratory comparison approach are in progress, so as to finalise production and release onto the market the brown algae CRM for trace metal analysis.
\end{abstract}

Keywords: brown algae, trace metals, certified reference material, fucus vesiculosus, environmental analysis. 


\section{Introduction}

In recent decades, marine pollution has been evaluated and monitored not only by analysing water and sediment, but also by using aquatic bioindicator organisms. Aquatic organisms, such as mussels and algae, have displayed the capacity to accumulate organic and inorganic pollutants; and algae, in particular, showed a significant uptake capacity for trace metals.

Among the three main groups of algae (brown, red and green), brown algae seem to have the highest biosorbent capacity, especially for $\mathrm{Cd}, \mathrm{Cu}, \mathrm{Zn}, \mathrm{Pb}, \mathrm{Cr}$ and $\mathrm{Hg}$ in water and wastewater [1,2]. Specifically, Fucus vesiculosus and Ascophillum nodosus have been increasingly used in water quality monitoring [3].

In this context, the Water Framework Directive [4], although not providing environmental quality standards for trace metals in brown algae, suggests the use of macroalgae as an indicator of water quality. Thus, a number of European countries (mainly Finland, Sweden, Germany and Great Britain) have used macroalgae (and in particular Fucus vesiculosus) as a marine bioindicator [5, 6].

Furthermore, Fucus vesiculosus is also used in food, cosmetic and clinical fields $[7,8]$ for its nutritional and therapeutic properties; increasing in this way the interest of the scientific community in monitoring the level of trace metals.

However, in trace metal monitoring, either in the environmental field or food market, the possibility of performing the analyses in a reliable and accurate way is of crucial importance. To this end, certified reference materials (CRMs) are developed with the specific scope of providing a common reference point useful for ensuring and improving the traceability of measurement results.

As specifically stated in ISO Guide 34 [9] and ISO Guide 35 [10], in order to be recognised as a reference material, special requirements have to be met. Furthermore, specific tests to prove its homogeneity and stability over a long period of time need to be performed.

By following these guidelines, raw Bladderwrack (species Fucus vesiculosus) was processed and tested at the Institute for Reference Material and Measurements (IRMM, Belgium), with the aim of producing a new CRM of brown algae for use in trace metals analysis.

\section{Processing}

Sixty kg of raw brown algae (Bladderwrack, Fucus vesiculosus) was collected at two sites in November 2009; Silver Strand beach and Spiddal in Galway (IRL). Plants were cut above the holdfast by using a sharp knife, immediately rinsed with seawater to remove debris and sand and then collected in bags. In the laboratory, plants were checked for large epiphytes and other animal material, quickly rinsed in freshwater and immediately frozen at $-20^{\circ} \mathrm{C}$. The collection was performed taking into account the seasonal variation of element content in algae [11]. Several authors have reported an increase in the content of some trace elements between January and February; whereas a significant decrease was observed during the summer period (July, August) [12]. 
Although the temporal variation of metals in algae has been differently interpreted in literature [13, 14], in our case, the algae were collected in November, so as to reduce the risk of collecting raw material during a period of potential seasonal instability.

The frozen raw material was transported to the IRMM (Belgium) in order to be processed under controlled humidity and temperature conditions.

Algae were washed with deionised water to eliminate sand excesses, dried in a drying cabinet (Elbanton, NL) at $25 \pm 5^{\circ} \mathrm{C}$ and milled by using a cryo-grinding vibrating mill (Palla mill, KHD, Humboldt-Wedag, Köln, DE) cooled at about $190^{\circ} \mathrm{C}$. One of the main parameters which can seriously affect the quality of a reference material is the homogeneity; potential sources of heterogeneity were reduced by accurate milling and sieving steps. The material was sieved at 125 $\mu \mathrm{m}$ and finally mixed for several hours by using a DynaMix CM200 (WAB, Basel, $\mathrm{CH}$ ).

Particle size distribution was checked by using a Sympatec Helos (ClausthalZellerfeld, DE) from the beginning to the end of the processing and as presented in Figure 1, the resulting material showed an average particle size of ca. $100 \mu \mathrm{m}$.
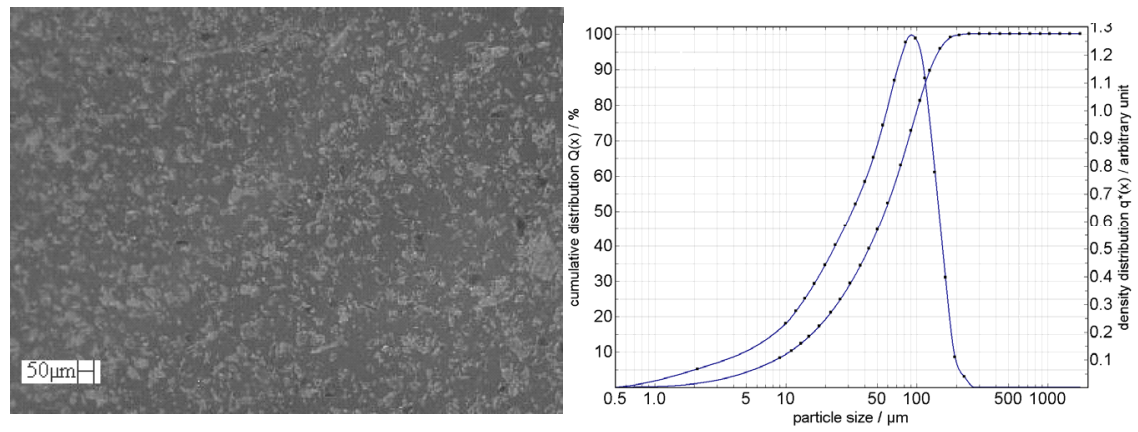

Figure 1: $\quad$ Typical micrograph for milled algae (left) and average particle size distribution obtained using isopropanol as dispersant (3 replicates, right).

During the whole processing, a loss of mass of ca. $85 \%$ was evidenced and the final portion recovered (with an average particle size of $<125 \mu \mathrm{m}$ ) corresponded to ca. $14 \%$ of the total raw material mass.

Water content and activity of the material are key points for the stability of a CRM over long periods of time. Moisture contents above 5\% can promote the growth of mould or enzyme activities with possible damage to the material [15]. Thus, the moisture level was decreased to $2.5 \%$ by vacuum drying the milled algae before bottling.

A large batch of about 1200 units was produced.

Possible causes of instability for the material generated during the processing were minimised by consistently working under controlled temperature and humidity and by filling the bottles in a glove box with a level of oxygen not exceeding $5 \%$. The degradation due to UV radiation was minimised by using 
amber glass bottles, which were later double sealed in aluminium pouches previously flushed with argon.

Finally, the bottles were sterilised by gamma irradiation with a maximum radiation dose of $15 \mathrm{kGy}$, in order to minimise any remaining bacterial activity.

\section{Water content determination}

Water content determination plays a significant role in evaluating uncertainties of measurements, as element mass fraction is usually reported dry-mass corrected [16]. Water content can be significantly different according to the method determination used. Oven drying for instance, though being a commonly used method, tends to underestimate the values; while Karl-Fischer titration is more selective for water particles, but less used because of its high costs.

It is therefore essential to establish the best conditions of determining water content in the material which should combine suitability for a large number of users and at the same time reliability.

Milled and sieved algae was checked for water content by using Karl-Fischer titration (765 KF Coulometer Methohm, $\mathrm{CH}$ ) and five different oven temperatures $\left(85^{\circ} \mathrm{C}, 95^{\circ} \mathrm{C}, 100^{\circ} \mathrm{C}, 105^{\circ} \mathrm{C}\right.$ and $\left.110^{\circ} \mathrm{C}\right)$ in order to establish the most reliable water determination method for the material [17].

As shown in Figure 2, the results obtained demonstrate a consistent increase in the apparent water content by increasing the oven temperature until $105^{\circ} \mathrm{C}$. Above $105^{\circ} \mathrm{C}$, the water content seems to decrease.

The value obtained with the Karl-Fischer titration was $10.0 \pm 0.3 \mathrm{~g} / 100 \mathrm{~g}$ (average of 6 replicates measurements \pm standard deviation), which was not found to be statistically different (F-test, $95 \%$ confidence level) from the value found with oven drying determination by using a temperature of $105^{\circ} \mathrm{C}$.

\section{Homogeneity and stability tests}

In order to perform specific homogeneity and stability tests, several bottles were selected from the whole batch produced, according to a randomly stratified scheme [18] and then stored and analysed in different conditions.

For the homogeneity study, 11 bottles were selected within the whole batch, digested by using $\mathrm{HNO}_{3}$ and analysed for the total content of $\mathrm{As}, \mathrm{Cd}, \mathrm{Cu}, \mathrm{Hg}, \mathrm{Pb}$, $\mathrm{Se}$ and $\mathrm{Zn}$ with ICP-SFMS (Inductively Coupled Plasma - Sector Field Mass Spectrometry) under repeatability conditions (i.e. in one analytical run).

The results evaluated by using one-way ANOVA, showed a standard deviation between bottles always below 5\% (Figure 3), confirming the homogeneity of the material.

Regarding the stability test, an isochronous scheme was followed. Eight bottles were stored at a temperature of $60^{\circ} \mathrm{C}$ for $0,1,2$ and 4 weeks (two bottles per time point), in order to simulate harsh environmental conditions. After the testing time, bottles were brought to a reference temperature of $-20^{\circ} \mathrm{C}$ so as to "freeze" their state and later on analysed together under repeatability conditions. 


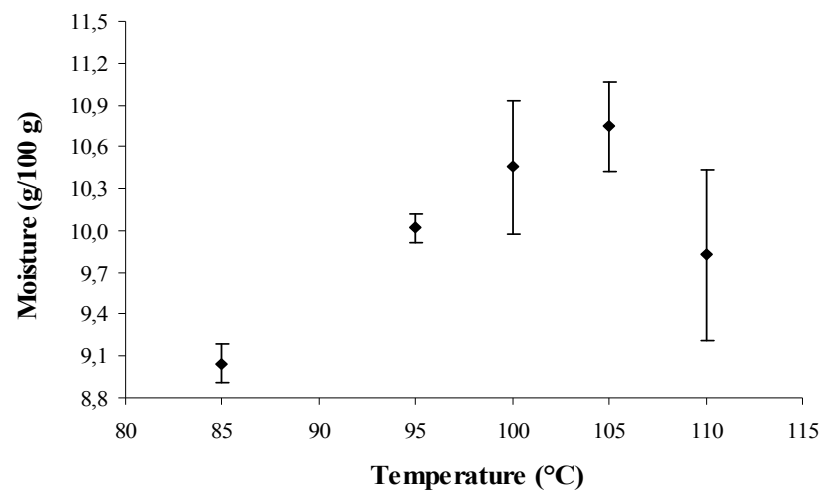

Figure 2: Water content $(\mathrm{g} / 100 \mathrm{~g})$ determination performed by using an oven drying method in brown algae (fucus vesiculosus). Bars correspond to standard deviation of 6 replicate measurements.

The results were obtained by digesting the samples with a mixture of $\mathrm{HNO}_{3}$, $\mathrm{H}_{2} \mathrm{O}_{2}$ and $\mathrm{HF}$ and by using ICP-OES (Inductively Coupled Plasma - Optical Emission Spectrometry) for $\mathrm{As}, \mathrm{Cd}, \mathrm{Cu}, \mathrm{Pb}$ and $\mathrm{Zn}$ and GF-AAS (Graphite Furnace - Atomic Absorption Spectrometry) for $\mathrm{Hg}$ and Se.

The selection of different digestion and measurement procedures was decided upon, in order to reduce the presence of biased results, related to problems arising from a specific method or procedure.

As for the homogeneity study, data were evaluated by using one-way ANOVA in order to detect any drifting of the elemental concentrations in the material over time. The slope of the linear regression was never found to be statistically significantly different from zero (Figure 4).

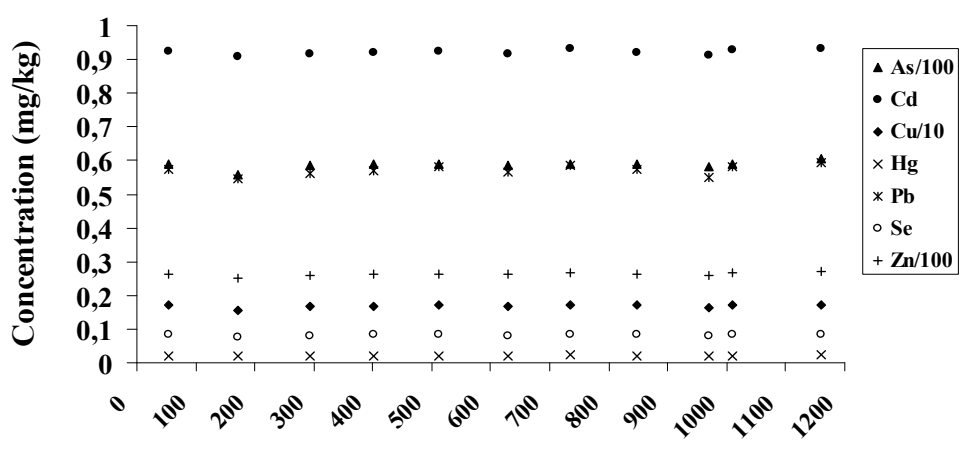

Bottle's number

Figure 3: Homogeneity study performed on 11 bottles. Data are reported dry mass corrected in $\mathrm{mg} / \mathrm{kg}$. As and $\mathrm{Zn}$ are reported divided by a factor of 100 and $\mathrm{Cu}$ by a factor of 10 . 


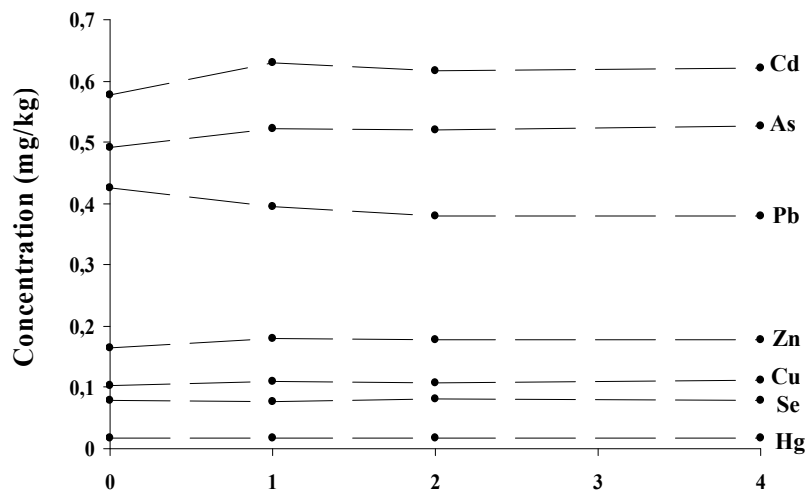

Time (weeks)

Figure 4: $\quad$ Stability study performed on 4 time points $(0,1,2$ and 4 weeks) at $60^{\circ} \mathrm{C}$. Data are reported dry mass corrected in $\mathrm{mg} / \mathrm{kg}$. As and $\mathrm{Zn}$ are reported divided by a factor of 100 and $\mathrm{Cu}$ by a factor of 10 .

Alongside this stability test, 14 bottles were stored, by using an isochronous study, for up to 12 months at a maximum temperature of $18^{\circ} \mathrm{C}$, with the aim of evaluating the sample stability over a longer period of time and providing an estimation of the future shelf-life of the material.

A preliminary characterisation study on two elements (As and $\mathrm{Zn}$ ) was performed by using neutron activation analysis $\left(\mathrm{k}_{0}-\mathrm{NAA}\right)$ as a primary method [19]. The values obtained were in the range of $40-60 \mathrm{mg} / \mathrm{kg}$ for As and 20-30 $\mathrm{mg} / \mathrm{kg}$ for $\mathrm{Zn}$ and thus comparable with the ones obtained during the homogeneity and stability tests (Figures 2 and 3).

A number of expert laboratories are currently being selected on the basis of specific quality criteria to take part in an inter-laboratory comparison campaign for the assignment of certified values for $\mathrm{As}, \mathrm{Cd}, \mathrm{Cu}, \mathrm{Hg}, \mathrm{Pb}, \mathrm{Se}$ and $\mathrm{Zn}$.

Key requirements in the selection are the use of different digestion methodology and analytical techniques, so as to minimise method dependant biases.

\section{Conclusion}

With the aim of producing a CRM for trace metal analysis in brown algae, several aspects concerning homogeneity and stability of the material, were checked. Homogeneity of the material was achieved during processing by employing an extensive milling and sieving procedure; specific preventive measures were taken to ensure stability, such as reducing the moisture content, bottling the material under an inert atmosphere and irradiating with a gamma source.

The homogeneity and stability tests performed so far show that the brown algae material is a good candidate for becoming a CRM. 
Along with these studies, characterisation of the total element content, by using an inter-laboratory comparison approach, is in progress, so as to finalise production and release onto the market the CRM for trace metal analysis in brown algae.

\section{References}

[1] Davis, T.A., Volesky, B. \& Mucci, A., A review of the biochemistry of heavy metal biosorption by brown algae-Review. Water Research, 37, pp. 4311-4330, 2003.

[2] Wang, J. \& Chen, C., Biosorbents for heavy metals removal and their future. Biotechnology Advances, 27, pp. 195-226, 2009.

[3] Mata, Y. N., Blázque, M. L., Ballester, A., González, F. \& Muñoz, J. A., Characterization of the biosorption of cadmium, lead and copper with the brown alga Fucus vesiculosus. Journal of Hazardous Materials, 158, pp. 316-323, 2008.

[4] European Commission, Directive 2000/60/EC of the European Parliament and of the Council establishing a framework for the Community action in the field of water policy, Off. J. Eur. Commun. L327.

[5] Amer, H. A., Ostapczuk, P. \& Emons, H., Quality assurance in measuring the elemental composition of the alga Fucus vesiculosus. Journal of Environmental Monitoring, 1, pp. 97-102, 1999.

[6] Daka, E.R., Allen, J. R. \& Hawkins, S. J., Heavy metal contamination in sediment and biomonitors from sites around the Isle of Man. Marine Pollution Bulletin, 46 (6), pp. 784-791, 2003.

[7] Teas, J., The consumption of seaweed as a protective factor in the etiology of breast cancer. Medical Hypotheses, 7(5), pp. 601-613, 1981.

[8] Burtin, P., Nutritional values of seaweeds. Electronic Journal of Environmental, Agricultural and Food Chemistry, 2 (4), pp. 498-503, 2003.

[9] ISO Guide 34, General requirements for the competence of reference material producers, 2000.

[10] ISO Guide 35, Reference materials - General and statistical principles for certification, 2006.

[11] O'Leary C. \& Breen L., Seasonal variation of heavy metals in Mytilus edulis, Fucus vesiculosus and sediment from the Shannon estuary, Biology and Environmental Proceedings of the Royal Irish Academy, 98B(3), pp. 153-159, 1998.

[12] Riget, F., Johansen, P. \& Asmund G., Natural seasonal variation of cadmium, copper, lead and zinc in brown seaweed. Marine Pollution Bulletin, 30(6), 409-413, 1995.

[13] Ströngren, T., Temperature-length growth strategies in the littoral alga Ascophyllum nodosum (L.). Limnology and Oceanography, 28(3), pp. 516-521, 1983.

[14] Villares, R., Puente, X. \& Carballeira A., Seasonal variation and background levels of heavy metals in two green seaweeds. Environmental Pollution, 119, pp. 79-90, 2002. 
[15] Igathinathane, C., Womac, A.R., Pordesimo, L.O. \& Sokhansanj, S., Mold appearance and modeling on selected corn stover components during moisture sorption. Bioresource Technology, 99, pp. 6365-6371, 2008.

[16] Zeiller, E. Benetka, E., Koller, M. \& Schorn, R., Dry mass determination: what role does it play in combined measurement uncertainty? Accreditation and Quality Assurance, 12, pp. 295-302, 2007.

[17] Vassileva, E. \& Quetel, C.R., Influence of the correction for moisture content on the quality of the certification of cadmium, copper and lead mass fractions in rice. Food Chemistry 106, pp. 1485-1490, 2008.

[18] D. S. Yates, D.S. Moore \& G. McCabe, The Practise of Statistics, W.H. Freeman \& Co., NY, 2003

[19] Greenberg, R. R., Bode, P., Nadai Fernandes, E. A., Neutron activation analysis: A primary method of measurement. Spectrochimica Acta Part B: Atomic Spectroscopy, in press. 